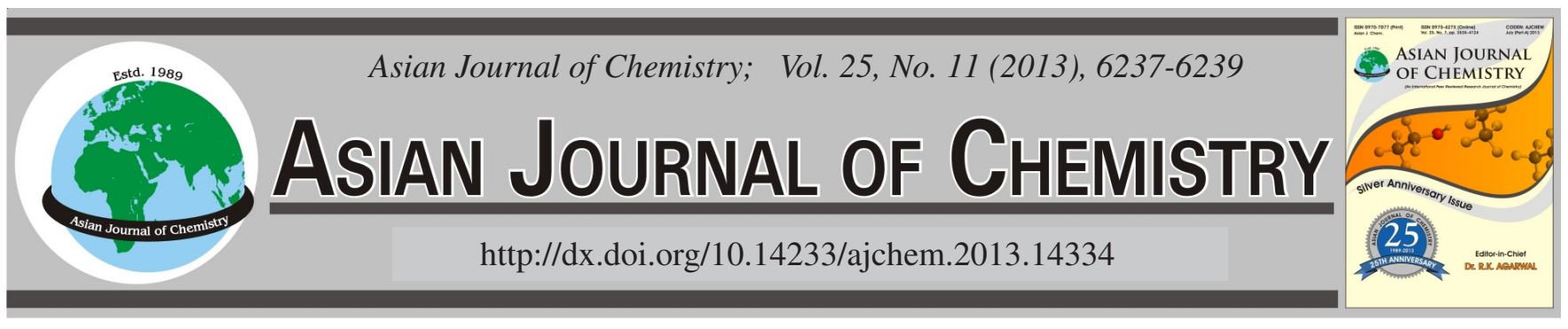

\title{
A Novel and Green Method for the Synthesis of Benzo-15-crown-5 Containing Sulphonylthiourea-Based Receptors
}

\author{
Cong-Wen Ding*, Yue-Feng Zhang and Hai-Feng Yu
}

Institute of Fine Chemical Industry, Department of Chemistry and Chemical Industry, College of Life Sciences, Tarim University, Alaer 843300, Xinjiang Province, P.R. China

*Corresponding author: Fax: +86997 4685622; Tel: +86997 4681612; E-mail: dingcw19731008@163.com

(Received: 19 July 2012;

Accepted: 2 May 2013)

AJC-13444

The nucleophilic reaction of 4'-aminobenzo-15-crown-5 and carbon disulphide in aqueous $\mathrm{KOH}$ afforded corresponding dithiocarbamate salt. Subsequent nucleophilic substitution reactions with sulfonamides aqueous $\mathrm{NaOH}$ provided benzo-15-crown-5-containing sulphonylthioureas. This novel, green method has the advantages of simple operation, high yields, easy product-isolation and environmental friendliness.

Key Words: Aqueous media, Benzo-15-crown-5-dithiocarbamate salt, Sulfonamides, Sulphonylthioureas.

\section{INTRODUCTION}

Thioureas-based anion receptors ${ }^{1}$ via hydrogen-bonding interactions including benzo-15-crown-5-containing thioureas ${ }^{2,3}$ are well known. The continued interest in novel thiourea ligands stems from their applications in many areas of chemistry and biochemistry, such as chromoionophore ${ }^{4}$, bifunctional organocatalyst $^{5}$, solar cell ${ }^{6}$ and easy complexation of $\mathrm{Ni}(\mathrm{II})^{7}$ and anions $^{8}$. Our ongoing studies are concerned with the simple, convenient preparation of these compounds. Several traditional methods have been developed for the synthesis of sulphonylthioureas involving: (a) reaction of sulphonylisothiocyanate and amine in dry $\mathrm{CCl}_{4}, \mathrm{CHCl}_{3}$ or $\mathrm{CH}_{2} \mathrm{Cl}_{2}{ }^{9-13}$; (b) reaction of sulfonamide and isothiocyanate in anhydride acetone, DMF or DMSO in the presence of strong base ${ }^{14-17}$. These traditional methods ${ }^{18}$ involve volatile and toxic organic solvent, hypertoxic thiophosgene or unstable sulphonylisothiocyanate and cumbersome product-isolation procedures.

We have recently reported the synthesis of sulphonylimidazolidinethione from monosulphonyldiamine and carbon disulphide by intramolecularly nucleophilic substitution in water $^{19}$. In continuation of our ongoing research on the development of new eco-friendly organic reactions, we utilized water as green solvent to present a novel method for the synthesis of benzo-15-crown-5-sulphonylthioureas from sulfonamides and benzo-15-crown-5-dithiocarbamate salts by intermolecularly nucleophilic substitution affording the desired products in excellent yields with a practical and easy workup procedure. The synthetic route is outlined in Scheme-I.

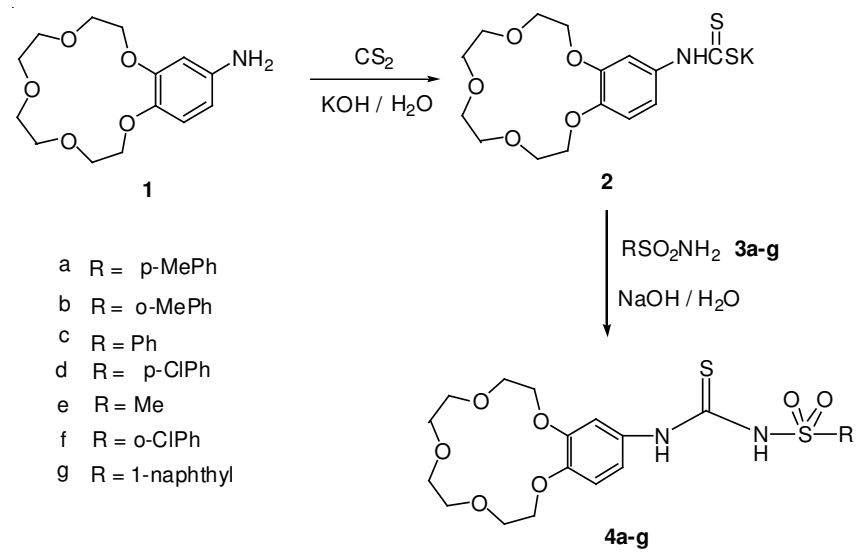

Scheme-I: Synthesis of sulphonylthiourea-functionalized benzo-15-crown-5 (4a-g) in water

\section{EXPERIMENTAL}

The reagents used were of reagent grade and used as purchased. Melting points were measured by using a XT-4 electrothermal micro-melting-point apparatus and are uncorrected. The progress of the reactions was monitored by TLC using silica-gel SIL G/UV $\mathrm{UV}_{254}$ plates and also by HPLC on RIGOL L-3000 instrument using THF-MeOH as the mobile phase on PGC column. NMR spectra were recorded at 400 $\left({ }^{1} \mathrm{H}\right)$ on a Bruker Avance III Plus 400 spectrometer in DMSO$d_{6}$ using TMS as internal reference. Chemical shifts $(\delta)$ are given in ppm. Infrared spectra were obtained on a Bio-Rad spectrophotometer using thin films on $\mathrm{NaCl}$ windows or in 
$\mathrm{KBr}$ pellets and are reported as $\mathrm{cm}^{-1}$. High resolution mass spectrum (HRMS) was recorded on PESCIEX API 2000 (triple quadrupole) mass spectrophotometer.

Typical procedure: To a solution of compound $\mathbf{1}$ (2.83 $\mathrm{g}, 10 \mathrm{mmol})$ and $\mathrm{KOH}(0.56 \mathrm{~g}, 10 \mathrm{mmol})$ in $\mathrm{H}_{2} \mathrm{O}(40 \mathrm{~mL})$ was added $\mathrm{CS}_{2}(50 \mathrm{mmol}, 3 \mathrm{~mL})$ and the mixture solidified in an ice-salt bath after stirring for $0.5 \mathrm{~h}$ at $35^{\circ} \mathrm{C}$. The dithiocarbamate salt was filtered, washed with a minimal amount of $\mathrm{Et}_{2} \mathrm{O}$-ethanol and added to little amount of warm water, thus aqueous compound 2 was isolated and obtained. A mixture of compounds 3a-g (10 mmol) and $\mathrm{NaOH}(0.84 \mathrm{~g}, 21 \mathrm{mmol})$ in $\mathrm{H}_{2} \mathrm{O}(60 \mathrm{~mL})$ was heated at $50{ }^{\circ} \mathrm{C}$. Agitation was continued for a further 45 min followed by dropwise addition of aqueous compound $\mathbf{2}$ with the reaction temperature being controlled at $50{ }^{\circ} \mathrm{C}$. The reaction mixture was cooled to room temperature and acidized with $2 \mathrm{M} \mathrm{HCl}$, The precipitated product was filtered off, washed with little amount of ethanol, dried and recrystallized from ethanol to give pale yellow needles $\mathbf{4 a - g}$.

Spectroscopic data of compound 4a: yield, $84 \%$; IR ( $\mathrm{KBr}$, $\left.v_{\max }, \mathrm{cm}^{-1}\right): 1090(\mathrm{C}=\mathrm{S}), 1360$ and $1180\left(\mathrm{SO}_{2}\right), 1142$ $\left(\mathrm{CH}_{2} \mathrm{OCH}_{2}\right), 1048\left(\mathrm{ArOCH}_{2}\right), 860$ (TsArH), 3220, $3280(\mathrm{NH})$. ${ }^{1} \mathrm{H}$ NMR (400 MHz, DMSO- $d_{6}$ ) $\delta$ (ppm): 2.34 (s, 3H, TsCH ${ }_{3}$ ), 3.34-4.11 (m, 16H, $\mathrm{CH}_{2} \mathrm{OCH}_{2}$ ), 6.60-6.84 (m, 2H, OArH), 7.23 (s, 1H, OArH), 7.48-7.56 (m, 4H, TsArH), 8.86 (s, 1H, NH), $11.23\left(\mathrm{~s}, 1 \mathrm{H}, \mathrm{SO}_{2} \mathrm{NH}\right)$. HRMS calcd for $\mathrm{C}_{22} \mathrm{H}_{28} \mathrm{~N}_{2} \mathrm{O}_{7} \mathrm{~S}_{2} \mathrm{~m} / \mathrm{z}$ 496.1315, found $\mathrm{m} / \mathrm{z} 496.1310$.

Compound 4b: Yield, $83 \%$; IR, $\left(\mathrm{KBr}, \mathrm{v}_{\max }, \mathrm{cm}^{-1}\right)$ : 1092 $(\mathrm{C}=\mathrm{S}), 1363$ and $1182\left(\mathrm{SO}_{2}\right), 1145\left(\mathrm{CH}_{2} \mathrm{OCH}_{2}\right), 1049$ $\left(\mathrm{ArOCH}_{2}\right), 770(o-\mathrm{MeArH}), 3225,3283(\mathrm{NH}) .{ }^{1} \mathrm{H}$ NMR (400 $\left.\mathrm{MHz}, \mathrm{DMSO}-d_{6}\right) \delta(\mathrm{ppm}): 2.35\left(\mathrm{~s}, 3 \mathrm{H}, o-\mathrm{CH}_{3} \mathrm{PhSO}_{2}\right), 3.33-$ $4.12\left(\mathrm{~m}, 16 \mathrm{H}, \mathrm{CH}_{2} \mathrm{OCH}_{2}\right), 6.59-6.83$ (m, 2H, OArH), 7.22 (s, $1 \mathrm{H}, \mathrm{OArH}), 7.46-7.52$ (m, 4H, o-MeArH), 8.85 (s, 1H, NH), 11.20 (s, 1H, $\mathrm{SO}_{2} \mathrm{NH}$ ). HRMS calcd. (\%) for $\mathrm{C}_{22} \mathrm{H}_{28} \mathrm{~N}_{2} \mathrm{O}_{7} \mathrm{~S}_{2}$ $\mathrm{m} / \mathrm{z}$ 496.1315, found (\%) m/z 496.1312.

Compound 4c: Yield, $85 \%$; IR $\left(\mathrm{KBr}, \mathrm{v}_{\max }, \mathrm{cm}^{-1}\right): 1094$ $(\mathrm{C}=\mathrm{S}), 1365$ and $1184\left(\mathrm{SO}_{2}\right), 1143\left(\mathrm{CH}_{2} \mathrm{OCH}_{2}\right), 1047$ $\left(\mathrm{ArOCH}_{2}\right), 760,710\left(\mathrm{SO}_{2} \mathrm{ArH}\right), 3222,3282(\mathrm{NH}) .{ }^{1} \mathrm{H}$ NMR (400 MHz, DMSO-d $d_{6} \delta(\mathrm{ppm}): 3.35-4.14(\mathrm{~m}, 16 \mathrm{H}$, $\mathrm{CH}_{2} \mathrm{OCH}_{2}$ ), 6.61-6.85 (m, 2H, OArH), 7.25 (s, 1H, OArH), 7.49-7.57 (m, 5H, SO $2 \mathrm{ArH}), 8.87$ (s, 1H, NH), 11.24 (s, 1H, $\mathrm{SO}_{2} \mathrm{NH}$ ). HRMS calcd. (\%) for $\mathrm{C}_{21} \mathrm{H}_{26} \mathrm{~N}_{2} \mathrm{O}_{7} \mathrm{~S}_{2} \mathrm{~m} / \mathrm{z} 482.1255$, found $(\%) \mathrm{m} / \mathrm{z} 482.1250$.

Compound 4d: Yield, $85 \%$; IR (KBr, $\left.v_{\max }, \mathrm{cm}^{-1}\right): 1093$ $(\mathrm{C}=\mathrm{S}), 1364$ and $1183\left(\mathrm{SO}_{2}\right), 1144\left(\mathrm{CH}_{2} \mathrm{OCH}_{2}\right), 1046$ $\left(\mathrm{ArOCH}_{2}\right), 850$ ( $p$-ClArH), 3223, $3281(\mathrm{NH}) .{ }^{1} \mathrm{H}$ NMR $(400$ $\left.\mathrm{MHz}, \mathrm{DMSO}-d_{6}\right) \delta(\mathrm{ppm}): 3.36-4.15\left(\mathrm{~m}, 16 \mathrm{H}, \mathrm{CH}_{2} \mathrm{OCH}_{2}\right)$, 6.63-6.87 (m, 2H, OArH), 7.24 (s, 1H, OArH), 7.47-7.54 (m, $4 \mathrm{H}, p$-ClArH), 8.84 (s, 1H, NH), 11.22 (s, 1H, SO $2 \mathrm{NH}$ ). HRMS calcd. (\%) for $\mathrm{C}_{21} \mathrm{H}_{25} \mathrm{~N}_{2} \mathrm{O}_{7} \mathrm{~S}_{2} \mathrm{Cl} \mathrm{m} / \mathrm{z} 517.0213$, found (\%) m/z 517.0211 .

Compound 4e: Yield $82 \%$; IR ( $\left.\mathrm{KBr}, \mathrm{v}_{\max }, \mathrm{cm}^{-1}\right): 1095$ $(\mathrm{C}=\mathrm{S}), 1361$ and $1181\left(\mathrm{SO}_{2}\right), 1148\left(\mathrm{CH}_{2} \mathrm{OCH}_{2}\right), 1048$ $\left(\mathrm{ArOCH}_{2}\right), 3224,3285(\mathrm{NH}) .{ }^{1} \mathrm{H}$ NMR $\left(400 \mathrm{MHz}, \mathrm{DMSO}-d_{6}\right)$ $\delta$ (ppm): 3.05 (s, 3H, $\left.\mathrm{CH}_{3} \mathrm{SO}_{2}\right), 3.32-4.10\left(\mathrm{~m}, 16 \mathrm{H}, \mathrm{CH}_{2} \mathrm{OCH}_{2}\right)$, 6.62-6.86 (m, 2H, OArH), 7.21 (s, 1H, OArH), 8.83 (s, 1H, $\mathrm{NH}), 11.19$ ( $\left.\mathrm{s}, 1 \mathrm{H}, \mathrm{SO}_{2} \mathrm{NH}\right)$. HRMS calcd. (\%) for $\mathrm{C}_{16} \mathrm{H}_{24} \mathrm{~N}_{2} \mathrm{O}_{7} \mathrm{~S}_{2} \mathrm{~m} / \mathrm{z}$ 420.5013, found (\%) m/z 420.5010 .

Compound 4f: Yield $81 \%$; IR (KBr, $\left.v_{\max }, \mathrm{cm}^{-1}\right)$ : 1091 $(\mathrm{C}=\mathrm{S}), 1362$ and $1185\left(\mathrm{SO}_{2}\right), 1147\left(\mathrm{CH}_{2} \mathrm{OCH}_{2}\right), 1045$
$\left(\mathrm{ArOCH}_{2}\right), 750(\mathrm{o}-\mathrm{ClArH}), 3225,3284(\mathrm{NH}) .{ }^{1} \mathrm{H}$ NMR $(400$ $\left.\mathrm{MHz}, \mathrm{DMSO}-d_{6}\right) \delta(\mathrm{ppm}): 3.37-4.16\left(\mathrm{~m}, 16 \mathrm{H}, \mathrm{CH}_{2} \mathrm{OCH}_{2}\right)$, 6.64-6.88 (m, 2H, OArH), 7.26 (s, 1H, OArH), 7.48-7.55 (m, $4 \mathrm{H}, o-\mathrm{ClArH}), 8.88(\mathrm{~s}, 1 \mathrm{H}, \mathrm{NH}), 11.25$ (s, $\left.1 \mathrm{H}, \mathrm{SO}_{2} \mathrm{NH}\right)$. HRMS calcd. (\%) for $\mathrm{C}_{21} \mathrm{H}_{25} \mathrm{~N}_{2} \mathrm{O}_{7} \mathrm{~S}_{2} \mathrm{Cl} \mathrm{m} / \mathrm{z} 517.0213$, found (\%) $\mathrm{m} / \mathrm{z}$ 517.0210 .

Compound 4g: Yield $80 \%$; IR (KBr, $\left.v_{\max }, \mathrm{cm}^{-1}\right)$ : 1096 $(\mathrm{C}=\mathrm{S}), 1366$ and $1186\left(\mathrm{SO}_{2}\right), 1144\left(\mathrm{CH}_{2} \mathrm{OCH}_{2}\right), 1050$ $\left(\mathrm{ArOCH}_{2}\right), 810\left(\mathrm{SO}_{2} \mathrm{NAH}\right), 3226,3287(\mathrm{NH}) .{ }^{1} \mathrm{H}$ NMR $(400$ $\left.\mathrm{MHz}, \mathrm{DMSO}-d_{6}\right) \delta$ (ppm): 3.31-4.13 (m, $\left.16 \mathrm{H}, \mathrm{CH}_{2} \mathrm{OCH}_{2}\right)$, 6.66-6.90 (m, 2H, OArH), 7.27 (s, 1H, OArH), 7.50-7.58 (m, $\left.7 \mathrm{H}, \mathrm{SO}_{2} \mathrm{NAH}\right), 8.90$ (s, $\left.1 \mathrm{H}, \mathrm{NH}\right), 11.26$ (s, 1H, $\left.\mathrm{SO}_{2} \mathrm{NH}\right)$. HRMS calcd. (\%) for $\mathrm{C}_{25} \mathrm{H}_{28} \mathrm{~N}_{2} \mathrm{O}_{7} \mathrm{~S}_{2} \mathrm{~m} / \mathrm{z}$ 532.6316, found (\%) m/z 532.6313 .

\section{RESULTS AND DISCUSSION}

Starting material $\mathbf{1}$ was prepared according to the published procedures ${ }^{2}$. A modification of the procedure of $\mathrm{Aksac}^{20}$ was used to obtain aqueous solution of compound 2, which was used for the following reactions. Benzo-15-crown5-based ligand ${ }^{3}$ used as $\mathrm{Na}^{+}$receptor and phase transfer catalyst could improve the water-solubility of $\mathbf{1}$ and nucleophilicity of $\mathrm{TsNH}^{-} \mathrm{Na}^{+}$moiety. The novel reaction for the preparation of title compounds $\mathbf{4 a - g}$ was carried out based on the procedures shown in Scheme-I.

The structures of compounds $\mathbf{4 a - g}$ were characterized by spectral (IR, ${ }^{1} \mathrm{H}$ NMR, HRMS) data. The infrared spectra of the thioureas 4a-g revealed a $\mathrm{C}=\mathrm{S}$ stretching vibration at 1090$1096 \mathrm{~cm}^{-1}$, two bands for the symmetrical and asymmetrical vibrations of the $\mathrm{SO}_{2}$ group at 1186-1180 and 1366-1360 $\mathrm{cm}^{-1}$ as well as $p-\mathrm{MePhSO}_{2}$ and $p-\mathrm{ClPhSO}_{2}$ out-of-plane $\mathrm{Ph}-\mathrm{H}$ bending vibration with two adjacent hydrogens at $850-860$ $\mathrm{cm}^{-1}$ in compounds $\mathbf{4 a}$ and $\mathbf{4 d}, o-\mathrm{MePhSO}_{2}$ and $o-\mathrm{ClPhSO}_{2}$ out-of-plane $\mathrm{Ph}-\mathrm{H}$ bending with four adjacent hydrogen at 750$770 \mathrm{~cm}^{-1}$ in case of compounds $\mathbf{4 b}$ and $\mathbf{4 f}, \mathrm{PhSO}_{2} \mathrm{C}-\mathrm{H}$ bending with five adjacent hydrogen at $710,760 \mathrm{~cm}^{-1}$ in case of compound $\mathbf{4 c}$ and 1-naphthyl $\mathrm{SO}_{2} \mathrm{C}-\mathrm{H}$ bending with four and three adjacent hydrogen at $810 \mathrm{~cm}^{-1}$ in case of compound $\mathbf{4 g}$. The N-H bis-protons bands appeared at 3226-3220 and 3287$3280 \mathrm{~cm}^{-1}$. The ${ }^{1} \mathrm{H}$ NMR data showed two broad singlets in the region $\delta 8.83-8.90$ and $11.19-11.26$ ppm for corresponding $\mathrm{NH}$ and $\mathrm{SO}_{2} \mathrm{NH}$ moieties, multiplets at $\delta 3.31-4.16 \mathrm{ppm}$ for $\mathrm{CH}_{2} \mathrm{OCH}_{2}$ of 4a-g. Multiplets at $\delta$ 7.46-7.52 and 7.48-7.55 ppm for four hydrogens of the $o-\mathrm{CH}_{3} \mathrm{Ph}$ and $o-\mathrm{ClPh}$ rings in compounds $\mathbf{4 b}$ and $\mathbf{4 f}$, at $\delta$ 7.48-7.56 and 7.47-7.54 ppm for four hydrogens of the $p-\mathrm{CH}_{3} \mathrm{Ph}$ and $p$-ClPh rings in compounds $\mathbf{4 a}$ and $\mathbf{4 d}$ as well as a singlet at 3.05 ppm for the three hydrogens of the $\mathrm{CH}_{3} \mathrm{SNO}_{2}$ moiety in 4e. Further evidence about the structure of the foregoing compounds $\mathbf{4 a - g}$ has been derived from their HRMS spectra which revealed the expected $\mathrm{m} / \mathrm{z}$ number of signals for thiourea-based receptors, respectively.

\section{Conclusion}

In summary, an operationally simple and environmentally benign protocol for the synthesis of sulphonylthioureafunctionalized benzo- 15 -crown- 5 in aqueous media is described. The mildness and eco-friendly nature of the reaction, short reaction times and impressive yields are the considerable 
advantages that make the present method superior to the existing methods for the preparation of sulphonylthioureas. More detailed studies on the mechanism and synthetic applications of this supramolecular receptors for cooperative binding of sodium ions and anions are currently under investigation.

\section{ACKNOWLEDGEMENTS}

The authors gratefully thank the Xinjiang Production and Construction Corps Ph.D. Funding of China (No. 2012BB014) for finanicial support.

\section{REFERENCES}

1. A.-F. Li, J.-H. Wang, F. Wang and Y.-B. Jiang, Chem. Soc. Rev., 39, 3729 (2010).

2. S. Nishizawa, K. Shigemori and N. Teramae, Chem. Lett., 1185 (1999).

3. F.D. Sokolov, D.A. Safin, M.G. Babashkina, N.G. Zabirov, V.V. Brusko, N.A. Mironov, D.B. Krivolapov, I.A. Litvinov, R.A. Cherkasov and B.N. Solomonov, Polyhedron, 26, 1550 (2007).

4. T. Hayashita, T. Onodera, R. Kato, S. Nishizawa and N. Terarnae, Chem. Commun., 755 (2000).
5. B. Wu, G.-G. Liu, M.-Q. Li, Y. Zhang, S.-Y. Zhang, J.-R. Qiu, X.-P. Xu, S.-J. Ji and X.-W. Wang, Chem. Commun., 3992 (2011).

6. Z. Ning, C. Yuan, H. Tian, Y. Fu, L. Li, L. Sun and H. Ågren, J. Mater. Chem., 22, 6032 (2012).

7. M.G. Babashkina, D.A. Safin, K. Robeyns and Y. Garcia, J. Chem Soc., Dalton Trans., 41, 1451 (2012).

8. W.-X. Liu, R. Yang and A.-F. Li, Z. Li, Y.F. Gao, X.X. Luo, Y.B. Ruan and Y.B. Jiang, Org. Biomol. Chem., 7, 4021 (2009).

9. J.W. McFarland and R.W. Houser, J. Org. Chem., 33, 340 (1968).

10. J.W. McFarland, T.H. Kozel, K.R. Stuhlmacher and T.S. Chevalier, J. Heterocycl. Chem., 17, 273 (1980).

11. C. Levallet, J. Lerpiniere and S.Y. Ko, Tetrahedron, 53, 5291 (1997).

12. A.M. Bowser and J.S. Madalengoitia, Org. Lett., 6, 3409 (2004).

13. I.-J. Kang, L.-W. Wang, S.-J. Hsu, C.-C. Lee, Y.-C. Lee, Y.-S. Wu, T.-A. Hsu, A. Yueh, Y.-S. Chao and J.-H. Chern, Bioorg. Med. Chem. Lett., 19, 4134 (2009).

14. H.-B. Zhang, Y.-A. Zhang, G.-Z. Wu, J.-P. Zhou, W.-L. Huang and X.-W. Hu, Bioorg. Med. Chem. Lett., 19, 1740 (2009).

15. K.-H. König, C. Holzner and J. Boßlet, Chem. Ber., 121, 1771 (1988).

16. J. Li, G. Zhang, Z. Zhang and E. Fan, J. Org. Chem., 68, 1611 (2003).

17. S.A.F. Rostom, Bioorg. Med. Chem., 14, 6475 (2006).

18. C.-W. Ding, M.-J. Zhang and N. Ma, Youji Huaxue, 30, 173 (2010).

19. C.-W. Ding, M.-J. Zhang and N. Ma, Chin. Chem. Lett., 20, 1166 (2009).

20. Z. Aksac, E. Pinar and S. Icli, Org. Magn. Reson., 21, 548 (1983). 